\title{
COMMENTARY
}

\section{Too early initiation of renal replacement therapy may be harmful}

\author{
Christophe Vinsonneau* and Mehran Monchi \\ See related research by Elseviers et al., http://ccforum.com/content/14/6/R221
}

\begin{abstract}
In an observational multicenter study, Elseviers and colleagues report that renal replacement therapy (RRT) in acutely ill patients treated for acute kidney injury is an independent risk factor for death. This result may question the benefit of the current practice of early RRT initiation.
\end{abstract}

In an observational study published in the previous issue of Critical Care, Elseviers and colleagues [1] report that the mortality of critically ill patients treated with renal replacement therapy (RRT) for acute kidney injury (AKI) is much higher than that of those treated by a conservative strategy (that is, without RRT). RRT remains an independent factor associated with a higher mortality after adjustments for acute disease severity (risk ratio [RR] 1.73, 95\% confidence interval [CI] 1.4 to 2.2) based on the Stuivenberg Hospital Acute Renal Failure (SHARF) score as well as other corrections for usually wellestablished prognostic factors (age, sex, Sequential Organ Failure Assessment [SOFA] score, type of AKI, delayed admission, and clinical conditions). This observation might have two alternative explanations: first, RRT per se could worsen the prognosis of acutely ill patients experiencing AKI; second, AKI of patients treated by RRT was more severe and this greater severity is not fully reflected by the severity scores and adjustment factors used in the multivariable models of the study. In fact, the role of AKI, as an independent factor for mortality, is currently well documented, regardless of the severity of AKI $[2,3]$. The subpopulation requiring RRT in the intensive care unit represents the more severe population, and the need for RRT appears to be an independent risk

*Correspondence: christophe.vinsonneau@ch-melun.fr

Department of Intensive Care Medicine, Melun General Hospital, 2, rue Freteau de Peny, 77000 Melun, France factor for death [4]. However, the need for renal supportive care is nonetheless a marker of severity. The specific role of RRT was first proposed by Guerin and colleagues [5] in their French epidemiological study. Indeed, they reported, in a multiple logistic regression analysis, that the absence of hemodialysis in their severe AKI population (serum creatinine $[\mathrm{sCr}]$ of greater than $300 \mu \mathrm{mol} / \mathrm{L}$, urine output of less than $500 \mathrm{~mL} / 24$ hours, or the need for hemodialysis) was a significant predictor of survival (odds ratio 1.78 , 95\% CI 1.05 to $3.04 ; P$ 0.032). This finding is of paramount importance given the current trend to initiate RRT early in the course of AKI. Moreover, recent epidemiological [6] or prospective controlled [7] studies show that the main criteria for RRT initiation are based on low urine output prior to a marked increase in $\mathrm{sCr}$ or serum urea level. RRT remains associated with a high mortality, and given the lack of survival improvement using continuous RRT [8] or augmented delivered dose [7,9], early initiation of RRT might be promising. Actually, numerous retrospective studies report a better outcome with earlier initiation, but conflicting results are reported by other studies [10]. Finally, a recent meta-analysis [11] shows a barely significant decrease in mortality using early initiation of RRT in prospective studies (RR 0.64, 95\% CI 0.40 to 1.05 ; $P<0.08)$ and a significant decrease in mortality using early initiation of RRT in observational studies (RR 0.72, 95\% CI 0.64 to $0.82 ; P<0.001)$. This new strategy seems attractive, but regarding the lack of strong data in favor of any beneficial effect, we should pay heed to the potential adverse effects. Unfortunately, the study by Elseviers and colleagues [1] presents many shortcomings, which hamper any definitive conclusion. First, the study is an observational trial and no prespecified criteria regarding RRT indications and the timing of initiation were provided in the different centers. This shortcoming may explain the heterogeneity in the rate of patients treated with RRT between the different centers and the associated mortality. Second, adjustment criteria did not take into account specific AKI characteristics, like oliguria, or specific prognostic scores based on metabolic 
disturbances (that is, RIFLE [Risk, Injury, Failure, Loss, and End-stage kidney disease] or AKIN [Acute Kidney Injury Network]). We can guess that intensivists were prompt to initiate RRT in patients with oliguria or severe metabolic abnormalities and thereby to select a more severe population. The higher mortality could be linked to the AKI severity itself rather than to a specific effect of RRT. The real problem in clinical practice is the early detection of AKI patients for whom RRT will be mandatory. In this population, we could probably start RRT early, whereas in the others, we could delay the initiation. As we wait for a large prospective study to test the benefit of early initiation of RRT, it seems reasonable, in the absence of a current clinical or biological marker of RRT requirement, to keep in mind that widespread use of early initiation may lead to an excess risk of complications and perhaps to a higher mortality than expected.

\section{Abbreviations}

$\mathrm{AKI}$, acute kidney injury; $\mathrm{Cl}$, confidence interval; $\mathrm{RR}$, risk ratio; $\mathrm{RRT}$, renal replacement therapy; $\mathrm{s} C r$, serum creatinine.

\section{Competing interests}

The authors declare that they have no competing interests.

Published: 26 January 2011

\section{References}

1. Elseviers MM, Lins RL, Van der Niepen P, Hoste E, Malbrain ML, Damas P, Devriendt J, (SHARF) Investigators SHARF: Renal replacement therapy is an independent risk factor for mortality in critically ill patients with acute kidney injury. Crit Care 2010, 14:221.

2. Joannidis M, Metnitz B, Bauer P, Schusterschitz N, Moreno R, Druml W, Metnitz PG: Acute kidney injury in critically ill patients classified by AKIN versus RIFLE using the SAPS 3database. Intensive Care Med 2009, 35:1692-1702.

3. Coca SG, Peixoto AJ, Garg AX, Krumholz H, Parikh CR: The prognostic importance of a small acute decrement in kidney function in hospitalized patients: a systematic review and meta-analysis. Am J Kidney Dis 2007, 50:712-720.

4. Metnitz PG, Krenn CG, Steltzer H, Lang T, Ploder J, Lenz K, Le Gall JR, Druml W: Effects of acute renal failure requiring renal replacement therapy on outcome in critically ill patients. Crit Care Med 2002, 30:2051-2058.

5. Guerin C, Girard R, Selli JM, Perdrix JP, Ayzac L: Initial versus delayed acute renal failure in the intensive care unit. Am J Respir Crit Care Med 2000, 161:872-879.

6. Uchino S, Bellomo R, Morimatsu H, Morgera S, Schetz M, Tan I, Bouman C, Macedo E, Gibney N, Tolwani A, Oudemans-van Straaten H, Ronco C, Kellum $J A$ : Continuous renal replacement therapy: a worldwide practice survey. The beginning and ending supportive therapy for the kidney (B.E.S.T. kidney) investigators. Intensive Care Med 2007, 33:1563-1570.

7. RENAL Replacement Therapy Study Investigators, Bellomo R, Cass A, Cole L, Finfer S, Gallagher M, Lo S, McArthur C, McGuinness S, Myburgh J, Norton R, Scheinkestel C, Su S: Intensity of renal replacement therapy in critically ill patients. NEngl J Med 2009, 361:1627-1638.

8. Vinsonneau C, Camus C, Combes A, Costa de Beauregard MA, Klouche K, Boulain T, Pallot JL, Chiche JD, Taupin P, Landais P, Dhainaut JF; Hemodiafe Study Group: Continuous venovenous haemodiafiltration versus intermittent haemodialysis for acute renal failure in patients with multiple-organ dysfunction syndrome: a multicentre randomised trial. Lancet 2006, 368:379-385.

9. VA/NIH Acute Renal Failure Trial Network, Palevsky PM, Zhang JH, O'Connor TZ, Chertow GM, Crowley ST, Choudhury D, Finkel K, Kellum JA, Paganini E, Schein RM, Smith MW, Swanson KM, Thompson BT, Vijayan A, Watnick S, Star RA, Peduzzi P: Intensity of renal support in critically ill patients with acute kidney injury. N Engl J Med 2008, 359:7-20.

10. Gibney RTN, Bagshaw SM, Kutsogiannis DJ, Johnston C: When should renal replacement therapy for acute kidney injury be initiated and discontinued. Blood Purif 2008, 26:473-484.

11. Seabra VF, Balk EM, Liangos O, Sosa MA, Cendoroglo M, Jaber BL: Timing of renal replacement initiation in acute renal failure: a meta-analysis. $A m$ J Kidney Dis 2008, 52:527-284.

doi:10.1186/cc9405

Cite this article as: Vinsonneau C, Monchi M: Too early initiation of renal

replacement therapy may be harmful. Critical Care 2011, 15:112. 